\title{
REVIEW \\ Paul R. Hinlicky \\ Before Auschwitz: What Christian Theology \\ Must Learn from the Rise of Nazism
}

(Eugene, OR: Cascade Books, 2013), paperback, xii +233 pp.

Robert Cathey, McCormick Theological Seminary

The author engages the reader in a historical-theological meditation on the implications of "the complicity of mainstream Christian theologians in Nazism” (p. 17). He relies upon Robert Ericksen's Theologians under Hitler (Gerhard Kittel, Paul Althaus and Emanuel Hirsch) (New Haven: Yale University Press, 1985) as foundational research for a new field in historical theology. Hinlicky reviews much of the literature published in German and English from his own theological perspective, summarized in his statement that "Christian theology can and must still learn from experience and produce knowledge that makes a difference," in opposition to so-called "death of God" theologians (p. 11), elaborated in six theological theses explicated in Chapter 5. His close readings of the literature in the field are insightful and his own theological perspective and theses are constructive and provocative. Chapter Four on "The Not So Strange Theology of Adolf Hitler" is the most distinctive. He reconstructs Hitler's own system of beliefs and reports that some of his students, misreading Hitler as the "champion of an enlightened scientific worldview," "could not possibly have favored racial or religious intolerance" (pp. 104-105).

Part of what Hinlicky uncovers is that neither Protestant theological liberalism (or revisionism) nor conservatism in the context of Germany of the 1920s and 30s had the moral, spiritual, and critical resources to save the German churches from becoming aligned with the Nazi cause. For some liberal 
German Christians, demythologizing biblical texts and reinterpreting the Gospel in light of the rise of National Socialism went hand in hand, especially when all the mythology (seen negatively) was ascribed to Judaism. In his second chapter, "The Peril of Conservative Apologetics," he argues against post-war apologists for the German Protestants who claim that "real Christianity, or the real Luther, or real Lutherans are not really to blame" for horrific evils of the Nazi era (p. 67). He draws from this the lesson in our own context that locating ourselves within the simple binary of liberal (or progressive) vs. conservative theology will not save us from the crises of twenty-first century global capitalism. We stand in need of a "critical dogmatics" that realizes "Neither those who attack nor those who defend succeed in understanding" the challenges and crises of the day (p. 11).

There is a tendency in the first three chapters to string together a series of condensed book reviews to cover the corpus of new historical and theological literature. This reader would have preferred that the author engage more directly with the historical and theological issues that are raised by the uses of theology under the Nazis. I also wondered whether readers who were not schooled in Lutheran theology would appreciate how much space is devoted to whether the "Two Kingdoms Doctrine" of Lutheranism was properly interpreted by the major theological figures and institutions of German Protestantism in the 1930 s. In fact, why should theologicalpolitical distinctions of the sixteenth century provide adequate explanatory language for a twentieth-century theological crisis (apart from the fact that this doctrine was used during the crisis)? What were the unique dimensions of this crisis that outstripped all inherited Christian norms?

Part of the value of this book for Christian-Jewish relations lies in the theological revisions Hinlicky proposes and argues for. For example, Christology "must account for the divergence between Christianity and Judaism over issues of the law without stigmatizing Jewish unbelief or questioning God's irrevocable calling of his ancient people, Israel. It must rather take Jewish 
unbelief in Jesus as the Messiah as a principle internal to its own theology" (p. 159). In light of this thesis we would benefit from hearing the author's thoughts on whether Christ after Auschwitz should still be proclaimed as the universal savior of all peoples, including the Jews. For the author, "The external word of the gospel concerning Christ includes the Jewishness of the man Jesus, because the ambiguity of his appearance in history is constituted by the well-grounded scriptural refusal of living Judaism to believe him. Only in the light of this refusal can Christian faith in Jesus as the Messiah and Son of God understand itself properly as faith, not sight" (p. 175). The implication seems to be that the Person and Work of Christ are salvific for the nations (the Gentiles) but unnecessary for Jesus' own Jewish people, whose covenant with God is irrevocable. Would the author be open to something like a "two covenant approach" to God's dealings with Jews and Gentiles, especially if the Jewish refusal of faith in Christ serves a positive theological function for Christians?

Finally, I wanted to ask the author at the end of each chapter and the book what were the implications of his research for how we critically evaluate Christian theology today with regard to particular movements and authors? He never specifies where he finds any contemporary theological movement or theologian falling into errors like those of Nazi-era theologians Paul Althaus, Gerhard Kittel, and Emanuel Hirsch. For example, are some forms of liberation theology too völkisch (too centered on one people's history and culture as divine revelation today)? Does the structure of anti-Judaism that Hinlicky criticizes in Nazi ideology and German Christian theology under Hitler reappear in some contemporary Christian theological critiques of Zionism and the State of Israel today (see, for example, Donald Wagner and Walter Davis, eds., Zionism and the Quest for Justice in the Holy Land. [Eugene, OR: Wipf \& Stock Publishers, 2014])? Are the "right to life" activists who invoke historical analogies between Nazi ideas of eugenics, racial purity, and genocide in the concentration camps, on the one hand, and the legal use of abortion as a means of birth control, on the other, onto something, or are 
they twisting history to their own ends? Perhaps the author wants his readers to draw their own conclusions about where their theologies and movements stand before and after Auschwitz. 